\title{
ORGANIZACIÓN DE UNIVERSIDADES CATOLICAS DE AMERICA LATINA (ODUCAL)
}

Universidad del Norte "Santo Tomás de Aquino"

San Miguel de Tucumán (Argentina)

1953

Tel: (81) 22-8805

President: Dr. Anibal S. Fósbery, Rector, Universidad del Norte "Santo Tomás de Aquino"

The purpose of the Organization is to promote the activities of Catholic higher education in Latin America, to assist in the cultural development of that region of the world, and to participate in educational progress. Its membership includes Catholic universities in Argentina, Brazil, Chile Colombia, Dominican Republic, Ecuador, Mexico, Nicaragua, Paraguay, Peru, Puerto Rico, and Venezuela.
Principal publications: Anuario; Sapientia; Universitas.

L' objet de l'organisation est de promouvoir les activités de l'enseignement supérieur catholique en Amérique latine, de soutenir le développement culturel de cette région du monde et de participer au progrès de l'éducation. Elle compte parmi ses membres des universités catholiques situées dans les pays suivants: Argentine, Bolivie, Brésil, Chili, Colombie, Equateur, Méxique, Nicaragua, Panamá, Paraguay, Pérou, Porto-Rico, République Dominicaine, Uruguay et Venezuela.

Publications principales: "Anuario", "Sapientia","UNIVERSITAS". 